\title{
WHEN URBAN PLANNING DOCTRINE MEETS LOW DENSITY COUNTRYSIDE
}

\author{
Maarit Sireni ${ }^{1}$
}

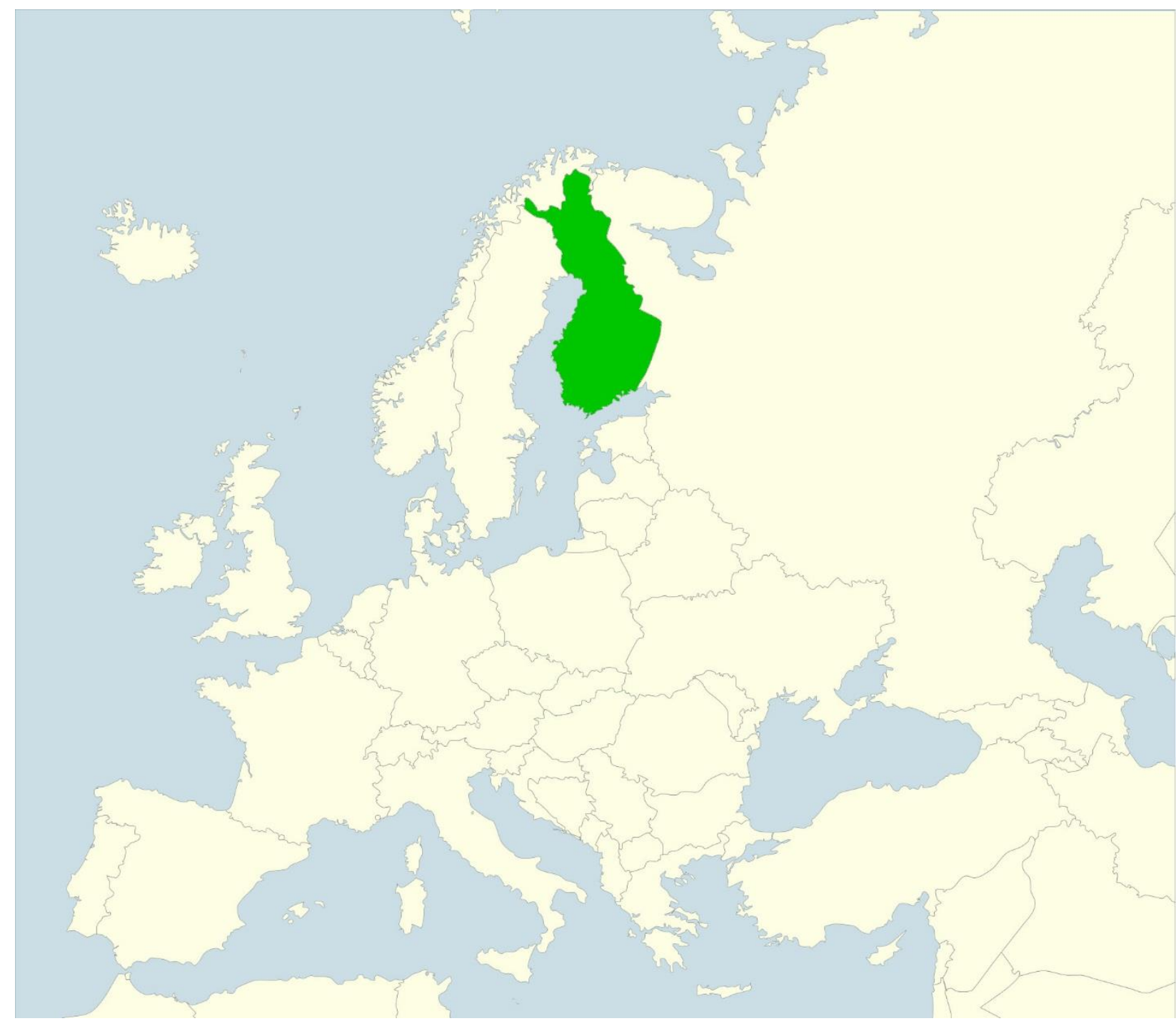

${ }^{1}$ Dr. Maarit Kastehelmi Sireni, Senior Researcher, Karelian Institute, University of Eastern Finland, Yliopistokatu 2, P.O. Box 111, FI 80101 Joensuu, Finland, e-mail: maarit.sireni@uef.fi 
Abstract: Drawing on an empirical analysis of Finnish local policy-makers' views on land use planning aims in rural areas, this paper investigates local responses to the new national planning regulations set out by the Government. According to the new norms, a dense settlement structure should be promoted not only in urban centres but also in rural areas in order to curb climate change and improve the viability of communities. Based on the data obtained from an internet-based survey conducted by a regional newspaper in western Finland before municipal elections in 2008 and 2012, this paper shows that the majority of the local policy-makers challenge the new norms. They do not believe that sustainable development can be promoted by constraining building rights in the rural region characterised by a dispersed settlement structure.

Key words: land use planning, climate change, rural areas, Finland

\begin{abstract}
Abstrakti: Artikkelissa analysoidaan suomalaisten kuntapoliitikkojen näkemyksiä siitä, tulisiko kuntien keskittää ja tiivistää asutustaan ilmastonmuutoksen hillitsemiseksi. Aineistona käytetään kuntavaalien 2008 ja 2012 alla kerättyä internetkyselyä, johon vastasi molempina vuosina noin tuhat ehdokasta Etelä-Pohjanmaalta. Artikkeli osoittaa, että kuntapäättäjät eivät kannata keskittämistä ja tiivistämistä, vaan suosivat sen sijaan hajautettua rakentamista eri puolille kuntaa. Näkemykset eivät ole muuttuneet neljässä vuodessa. Kantaa perustellaan ennen kaikkea alueiden ja ihmisten välisen tasa-arvon turvaamisella. Ilmastonmuutos ja ympäristösyyt eivät ole keskeisiä argumentteja, kun kuntapäättäjät perustelevat näkemyksiään maankäytön suunnittelun tavoitteista.
\end{abstract}

Avainsanat: maankäytön suunnittelu, ilmastonmuutos, maaseutu, Suomi

\title{
1. Introduction
}

Planning in rural areas has been focused on preventing urban sprawl and protecting agricultural land from building development (Lapping, 2006; Alexander, 2006). In several European countries where the demand for rural space is high, preservationist arguments centred upon protecting the countryside and farmland from concreting have received additional support from arguments which relate to the sustainability of communities. House building in rural areas has been seen to result in car-dependent residents with environmentally damaging greenhouse gas emissions, so undermining the concept of sustainable development (Curry and Owen 2009; Gkartzios and Scott, 2010; Sturzaker and Shucksmith, 2011). Given these restrictions to rural housing, rural space has increasingly become a luxury which is affordable only to a prosperous elite, and unobtainable to a majority of ordinary people (Sturzaker, 2010; Sturzaker and Shucksmith, 2011).

This paper investigates rural planning, housing rules and practices in Finland, where house building in rural areas has traditionally been loosely regulated (Ministry of the Environment, 2012). Until recently, the possibility to build isolated dwellings on one's own land without an extant local detail plan has been widely accepted as a form of common law based civil rights, and respected by local planning authorities and democratically elected decision-makers (Mäntysalo, Saglie and Cars, 2011: 2117). In general, this practice offers a route to spacious housing in a green environment, and reflects the traditionally strong position of landowning in both the Finnish mentality and in land use legislation (Othengrafen, 2010: 97).

More recently, this traditional laissez-faire rural land use planning regime has met with growing criticism from the Government, which sets the guidelines for land use planning and construction (Ministry of the Environment, 2009). The arguments used in support of a place-neutral land use planning policy, that is, of harmonising urban and rural planning standards, derive from similar conceptualisations of sustainable communities as seen in several other countries in Europe (e.g. Sturzaker and Shucksmith, 2011). The traditional multifunctional approach (i.e. a mixed land use of dwellings, forest and farmland in the countryside), has been defined as ecologically and 
economically unsustainable. A new model is conceptualised for use in all types of areas regardless of their degree of urbanisation or distance from urban centres, and features highdensity housing in compact residential areas, close to work places and services. This settlement pattern is promoted in order to "curb climate change, improve the viability of communities, and save on costs" (Ministry of the Environment, 2009: 3).

Drawing on an empirical analysis of local politicians' views on land use planning in rural areas, this paper investigates local responses to the new planning norms and ideals set out by the Government. In particular it asks: How do local politicians see the principle that a dense settlement structure contributes to sustainable development in the countryside, and which arguments do they put forward in support of their views? The paper aims at unpacking the differences between national and local interpretations of land use planning guidelines, and interprets local politicians' context-specific and culture-based views on these new principles.

The paper is structured as follows: Section 2 describes the Finnish planning system in which local authorities and policy-makers have traditionally played a central role. It outlines the context by introducing the Finnish planning culture with a focus on the changing ideologies and policies which affect rural planning (Othengrafen, 2010). Section 3 offers the empirical research setting and method, and is followed by the results of the study conducted in the archetypal region of the Finnish countryside, in Southern Ostrobothnia in western Finland (Section 4). The paper concludes with a discussion of the findings (Section 5).

\section{Land use planning in the Finnish countryside}

\subsection{The planning system}

In the Finnish land use planning system, formal decision-making has to a large degree traditionally been in the hands of the municipal councils. Both local master plans and local detailed plans which determine actual land use at a local level, are prepared and approved by the local authorities and political decision-makers (Böhme, 2002: 288). Local master plans set out the main goals and principles for detailed planning and development, and local detailed plans regulate land use and building rights at grass roots level. In Finland, as well as in its Nordic neighbours Norway and Sweden, local governments have traditionally been highly autonomous from national-level guidance and central state controls (OECD, 2005: 163; Mäntysalo, Saglie and Cars, 2011: 2113). This autonomy of local governments in respect to physical planning is connected to the municipalities' central role in implementing the Nordic welfare state model (Kettunen, 2001; Harvold and Nordahl, 2012: 215).

Although land-owners' rights are not explicitly stated in the planning laws, the extensive "basic building right" seen in the countryside is a deep-rooted practice, and derives from the specific needs of a former forestry-based agrarian society. During this productionist phase, scattered settlement structure was both reasonable and necessary as forestry all over the country required a labour force (Katajamäki, 1991). Since the $18^{\text {th }}$ century, land use in rural areas has been more loosely regulated than that in rural villages or urban areas (Ministry of the Environment, 2012: 17). Since the 1940s, house-builders have been required to have building permission granted by the local authorities, who have typically been supportive of private landowners' endeavours.

More recently, low-density housing has become an important strategy for rural development in the post-productionist countryside, and local authorities and politicians have recognised the potential embedded in people's housing preferences. A number of studies indicate that lowdensity housing in the green environment is esteemed highly by Finns, regardless of their education, income level or other background factors (Kortteinen, Tuominen and Vaattovaara, 2005; Juntto, 2007; Vasanen, 2012). As a result, rural regions have adopted low-density housing as a relevant strategy to maintain their population numbers and to attract new tax-payers. This approach has also been utilised by municipalities, especially those on the outskirts of urban regions, and has materialised in the deconcentration of urban populations, especially around the growing capital city of Helsinki, but also to a lesser degree in the surroundings of 4-8 smaller urban centres (Helminen and Ristimäki, 2007: 67). 
The autonomy of municipal governments in land use decisions has recently been challenged by the Government which revised the national land use planning guidelines in 2009. In principle, the Finnish land use planning system is hierarchically organised in three tiers, and higher level plans tend to steer lower level plans. The Ministry of the Environment has the right to define and redefine - the national land use guidelines, which should be taken into account throughout the country in all land use decisions and planning. The guidelines should be implemented both at the regional level through regional plans, and at the local level through local master plans and local detailed plans. However, these revised guidelines have undermined the tasks and practises of local policy makers in land use planning, and the factors conditioning this change and its implications are investigated in this paper.

\subsection{The cultural context}

Frank Othengrafen (2010) has highlighted the importance of specific cultural contexts in understanding different planning practices across Europe. His focus is on spatial planning, which is an umbrella term encompassing elements of national and transnational planning, regional policy, and detailed land use planning. Spatial planning not only controls and regulates present activities, but it also has a strategic orientation to bring out changes that otherwise would not occur (Othengrafen, 2010: 85). In his comparative analysis of the cultural guidelines underlying Finnish planning practices, Othengrafen (2010: 97) firstly identifies that many Finns wish to live "close to nature" as being one of the shared values that are taken for granted by planning professionals. The importance of nature and a "space of your own" to Finnish citizens have been interpreted to derive from the society's relatively brief history of urbanisation and urban living, and an idealisation of rural living environments (Kortteinen, Tuominen and Vaattovaara, 2005; Lapintie, 2010). Nature, solitude surroundings, wilderness and open space are also recognised as central driving forces behind the wish to own a second home in the countryside (Vepsäläinen and Pitkänen, 2010; Hiltunen and Rehunen 2014).

Secondly, Othengrafen (2010: 98-99) argues that Finnish planning cultures seem to be accompanied by such underlying perceptions and principles as "accuracy", "order" and "discipline". These attitudes are "cultural deeply rooted within the society so that public rules and norms - including guidelines of spatial plans - reach a high degree of legal commitment". He interprets this to reflect "society's higher confidence in the central state, which seems to be closely connected to the question of social justice", which implies that a lot of emphasis has been put on the reduction of regional disparities, the provision of equal living conditions in every part of the country, and nationwide comprehensive public approaches and services as an integral part of the task of the welfare state. During the heyday of the welfare state, the value of social justice concretised in urban planning, for instance, in the high share of social or subsidised housing, and in the social mix of neighbourhoods, housing types and income groups (Vaattovaara, Schulman and Kortteinen, 2011). In rural contexts however, it referred mainly to an equal access to infrastructure and public services, regardless of one's place of living.

\subsection{The place of rural space in the 'competition state'}

Here, it is argued that the cultural framework in which planning is embedded has been changing radically, hand-in-hand with the state restructuring which has occurred in Finland since the beginning of the 1990s (Moisio and Leppänen, 2007; Moisio, 2008). The transformation from a "Keynesian welfare state" to a "Nordic competition state" increasingly revolves around the spatial dimension of statehood, and has led to growing tensions in the field of regional politics and planning (Moisio, 2008). In the discursive field of the competition state, old principles such as the reduction of regional disparities have been increasingly constructed as barriers which have delayed and prevented the development of a "truly competitive state space". Therefore, a key dimension of the current debate on state transformation touches upon the issue of getting out of this Keynesian welfare state tradition. As Moisio (2008: 1) puts it: "the welfare spatiality which was based on social compromise and a particular decentralised settlement structure has been increasingly challenged in pro-business argumentation which emphasises the need to create economically effective, centralised as well as internationally attractive state space". In this vein, in the public debate on regional policy, traditional views of the "cultural importance of all regions" 
have been to a large degree replaced by views which emphasise the "support of growth centres" (Remahl, 2008). In the Government's documents, such as that concerning the "Competitiveness, welfare and eco-efficiency" of the long-term development of land use and spatial structure in Finland (Ministry of the Environment, 2006), internationally attractive and competitive state space associates with a polycentric spatial structure based on a dynamic network of cities, which attract global capital and top know-how.

This doctrinal re-orientation has inevitably influenced the relationship between the Finnish state and the rural space, and in turn, this raises the question whether rural Finland has an economic role of its own in the competition state (Rosenqvist, 2003). In the rhetoric of the drive towards international competitiveness, the rural space is constructed as subordinate to growth centers which are described as "engines pulling the growth" in rural regions (Remahl, 2008; Ministry of the Environment 2006: 11). Those rural areas which lie close to cities are seen to have best opportunities for attracting business, residents and urban consumers. However, given the fact that Finland's spatial structure is highly different from European averages, the urban network fails to cover the whole country, and thus large inhabited areas without "locomotives" remain in "no town land" between the urban regions. This difference has traditionally been described by comparing population densities, which in Finland are approximately one-tenth of those seen in Western and Central Europe. More recently, the concept of sparsity has been introduced to identify the distinctive features of Finnish (and Nordic) spatial characteristics, and to point out their implications. It refers to the fact that in addition to a low average density, the settlement pattern is dispersed with most parts of the country being thinly but thoroughly populated rural areas (Gløersen et al, 2005).

This distinctive spatial structure and its repercussions have recently received much negative attention in political and scholarly debates. With regard to domestic regional development policy and EU cohesion policy for instance, it is commonly argued that sparsity poses challenges to the key targets of these policies (i.e. an inclusive society and a competitive economy), basically for the reason that local demand is low in such conditions. This raises unit costs in public and private service provision, infrastructure costs are high, and agglomeration benefits are not available. As Damsgaard et al. (2008: 7) observe: "Sparsity leads to a series of challenges in terms of economic development and public and private service provision". In a rural context, the crucial concern is that the provision of equal living conditions in every part of the country has become a highly contested philosophy. For instance, this argument is put forward in the justifications of "the local government reform" which is strongly promoted by the government (Ministry of Finance, 2012), and the need to reorganise municipalities and the provision of services in terms of larger and fewer units is argued for by referring to demographic factors (ageing and depopulation) and municipal finance considerations (Ministry of Finance, 2012: 7).

In addition to these well-established arguments, in recent years the implications of decentralised settlement structures and sparsity have been discussed from the perspective of ecological sustainability. The above mentioned spatial strategy document issued by the Ministry of the Environment (2006) emphasises the key roles of the Helsinki Metropolitan Region and other major urban regions as drivers of the Finnish economy, and the need to promote ecological sustainability is argued mainly on grounds that it improves the attractiveness of those urban regions, which compete globally for enterprises and human capital. In operational terms, this ecoeffectiveness is primarily seen to refer to a compact urban structure and well-functioning public transport system, but which have so far been unattainable goals, especially in the growing and dispersing Helsinki region (Helminen and Ristimäki, 2007). In support of this argumentation, it is underlined that Helsinki and its surroundings have been judged to represent a warning example of urban sprawl (EEA, 2006). Therefore, for ecological sustainability, it is seen as essential that "the existing built environment and infrastructures are used extensively", and "regional and community structures are geared to decrease transport need" (Ministry of the Environment, 2006: 18). In recent years, this emphasis on ecological sustainability in land use (which reflects the prevalent European and global trends) is also clearly set in other planning documents such as the revised national land use guidelines which formulate the sustainability aim in more operational terms: "Climate change will mainly be curbed by reducing the volume of traffic, which is the aim of creating a more coherent urban structure" (Ministry of the Environment, 2009: 7). 
These same guidelines, which originate from urban planning traditions and are mainly targeted to respond to the challenges of urban sprawl, are seen to apply as the guiding principle in planning in all types of regions, including sparsely populated rural municipalities. By defining these comprehensive national planning rules, the Government has made a strong effort to interfere, and to intensify its guidance in regard to both regional and local-level planning (Mäntysalo, Saglie and Cars, 2011: 2113).

For the purposes of this study, it is particularly interesting that most national political parties support a dense and compact settlement structure for environmental reasons in their official documents (Table 1). The exception to this is the Centre Party ${ }^{2}$, which argues in support of building rights, even in sparsely populated areas. Also, the populist Perussuomalaiset (The Finns Party) makes an exception, emphasising individuals' rights and opposing planning and what is referred to as the "over-protection" of the environment.

Tab 1. Political parties' views on a settlement structure: what kind of structure and why? Sources: The platforms of: Finnish Social Democratic Party 2008: 11-13; Left Alliance 2008: 3; National Coalition Party 2008: 26-27; The Centre Party 2008: 13-14; The Finnish Christian Democrats 2008: 13; The Greens 2008: 2; Perussuomalaiset 2008: 16-17.

\begin{tabular}{|c|c|}
\hline Political party & What kind of structure and why? \\
\hline \multicolumn{2}{|l|}{ Left-wing } \\
\hline - Social Democratic Party & $\begin{array}{l}\text { Dense structure for environmental reasons (climate } \\
\text { change). }\end{array}$ \\
\hline - Left Alliance & $\begin{array}{l}\text { Dense structure for environmental reasons (climate } \\
\text { change). }\end{array}$ \\
\hline \multicolumn{2}{|l|}{ Right-wing } \\
\hline - National Coalition Party & $\begin{array}{l}\text { Dispersed settlement must be avoided for economic (extra } \\
\text { costs in providing services) and environmental reasons } \\
\text { (climate change). }\end{array}$ \\
\hline \multicolumn{2}{|r|}{ thering } \\
\hline - $\quad$ Centre Party & $\begin{array}{l}\text { Dense structure in urban areas for environmental reasons } \\
\text { (climate change). In rural areas, a dispersed structure is } \\
\text { acceptable. Building rights in sparsely populated areas } \\
\text { should not be restricted. }\end{array}$ \\
\hline - Christian Democrats & $\begin{array}{l}\text { Dense structure for environmental reasons (climate } \\
\text { change). }\end{array}$ \\
\hline - Greens & $\begin{array}{l}\text { Dense structure for environmental reasons (climate } \\
\text { change). }\end{array}$ \\
\hline \multicolumn{2}{|l|}{ Populist } \\
\hline - Perussuomalaiset & $\begin{array}{l}\text { Individuals' rights should not be restricted for } \\
\text { environmental reasons. Land-use planning must not } \\
\text { hinder individuals from building wherever they want to live. }\end{array}$ \\
\hline
\end{tabular}

From an urban perspective, the Government's efforts to control local-level planning typically appears to be a positive initiative, by reason that there is often a tension between the central city and its neighbouring municipalities which compete for enterprises, retailers and residents. This tends to result in striking differences in local-level planning policies, and in the municipalities surrounding the urban centre having much more developer- and landowner-driven planning policies, due to, for instance the lack of publicly owned land (Mäntysalo, Saglie and Cars, 2011: 2113). These semi-rural municipalities often aim at securing investments, and attract new taxpayers by smoothly allowing building projects - such as car-based shopping centres outside the urban areas - which are contrary to higher order plans. Against this background, it is especially in the interests of central cities to strengthen "the strategic planning" by limiting

\footnotetext{
2 The ideology of the Centre Party includes ingredients from both social democratic and liberal movements. It is a member of the European Liberal Democrats Party (ELDR) within the European Parliament.
} 
the planning power of local governments and locally elected politicians. From the point of view of semi-rural municipalities, this kind of interference appears in many cases to pose a threat to their "Space is Luxury" development strategies, which are based on marketing attractive building sites and providing migrants and enterprises with various incentives. However, this does not apply in the same straightforward way to remote and sparsely populated rural municipalities, which do not meet similar urban demand and land use pressures.

Against this background, this paper attempts to shed light on the ongoing political debate in rural areas, focusing on development strategies with regard to the objectives of economic competitiveness, social and spatial equity, and environmental sustainability. The following empirical investigation analyses the views of local decision-makers concerning spatial structure, establishing whether they (that is, those responsible for planning and building rights at a local level) would like to promote a dense or dispersed settlement structure, and which arguments they put forward in support of their views.

\section{Empirical setting}

\subsection{Survey material}

The empirical data consist of the views of local politicians concerning the major aims of land use planning. They represent 18 municipalities in the Southern Ostrobothnia region of western Finland (Figure 1). In a European context, this region can be seen as an example of an area of low population density and dispersed settlement structure, even if it is not the most extreme case of sparsity in Finland. The region covers an area of 14000 sq. kilometres, and its total population is slightly less than 200000 . With the exception of the regional centre (Seinäjoki), the municipalities are small in regard to their population numbers, and a considerable share of their population lives in non-urban settlements (Table 2). Despite their rural characteristics, seven of the municipal areas have the official status of a town ${ }^{3}$.

Tab 2. The key characteristics of the municipalities in the Southern Ostrobothnia region in 2012. Source: Statistics Finland

\begin{tabular}{|c|c|c|c|c|c|c|}
\hline & $\begin{array}{l}\text { Populati } \\
\text { on } \\
\text { number }\end{array}$ & $\begin{array}{l}\text { Size, } \\
\text { land } \\
\text { (sq. } \\
\text { km) }\end{array}$ & $\begin{array}{l}\text { Distance to } \\
\text { the regional } \\
\text { centre }(\mathrm{km})\end{array}$ & $\begin{array}{l}\text { Share of } \\
\text { employees } \\
\text { working in } \\
\text { agriculture (\%) }\end{array}$ & $\begin{array}{l}\text { Share of } \\
\text { employees } \\
\text { working outside } \\
\text { the local area } \\
(\%)\end{array}$ & $\begin{array}{l}\text { Share of } \\
\text { people living } \\
\text { in low- } \\
\text { density } \\
\text { areas (\%) }\end{array}$ \\
\hline $\begin{array}{l}\text { Regional centre } \\
\text { Seinäjoki }\end{array}$ & 59000 & 1400 & 0 & 3 & 17 & 10 \\
\hline \multicolumn{7}{|l|}{ Small towns } \\
\hline - $\quad$ Alajärvi & 10300 & 1000 & 70 & 12 & 21 & 41 \\
\hline - $\quad$ Alavus & 12500 & 1100 & 55 & 12 & 21 & 42 \\
\hline - $\quad$ Kauhajoki & 15000 & 1300 & 65 & 11 & 20 & 34 \\
\hline - Kauhava & 17200 & 1300 & 40 & 13 & 19 & 37 \\
\hline - Kurikka & 11000 & 900 & 33 & 10 & 34 & 30 \\
\hline - Lapua & 14000 & 700 & 28 & 10 & 37 & 25 \\
\hline - $\quad$ Ähtäri & 6400 & 800 & 80 & 10 & 23 & 38 \\
\hline \multicolumn{7}{|l|}{ Rural municipalities } \\
\hline - Evijärvi & 2900 & 350 & 82 & 29 & 34 & 65 \\
\hline - Ilmajoki & 12000 & 600 & 17 & 15 & 53 & 27 \\
\hline - Isojoki & 2500 & 600 & 88 & 25 & 25 & 62 \\
\hline - Jalasjärvi & 8500 & 800 & 35 & 20 & 29 & 54 \\
\hline - Karijoki & 1500 & 200 & 91 & 28 & 38 & 50 \\
\hline - Kuortane & 4300 & 500 & 41 & 16 & 35 & 60 \\
\hline - Lappajärvi & 3600 & 400 & 79 & 20 & 28 & 50 \\
\hline - $\quad$ Soini & 2500 & 550 & 84 & 15 & 28 & 54 \\
\hline - $\quad$ Teuva & 5800 & 550 & 80 & 16 & 28 & 36 \\
\hline - Vimpeli & 3200 & 300 & 84 & 9 & 30 & 33 \\
\hline
\end{tabular}

\footnotetext{
${ }^{3}$ In Finland, it is up to municipalities themselves whether they want to be termed as towns or municipalities.
} 
In the Finnish context, Southern Ostrobothnia can be characterised as a representative example of conservative and rural traditions, in comparison to national averages. The region is typical of the heart of the Finnish countryside in the sense that agriculture (primarily based on family farms) plays a more important role in the region's economy than in the Finnish countryside on average. In regard to political traditions, the left-wing parties and Greens are relatively weak in Southern Ostrobothnia, whereas the more conservative Centre Party and the right-wing National Coalition Party are relatively strong.

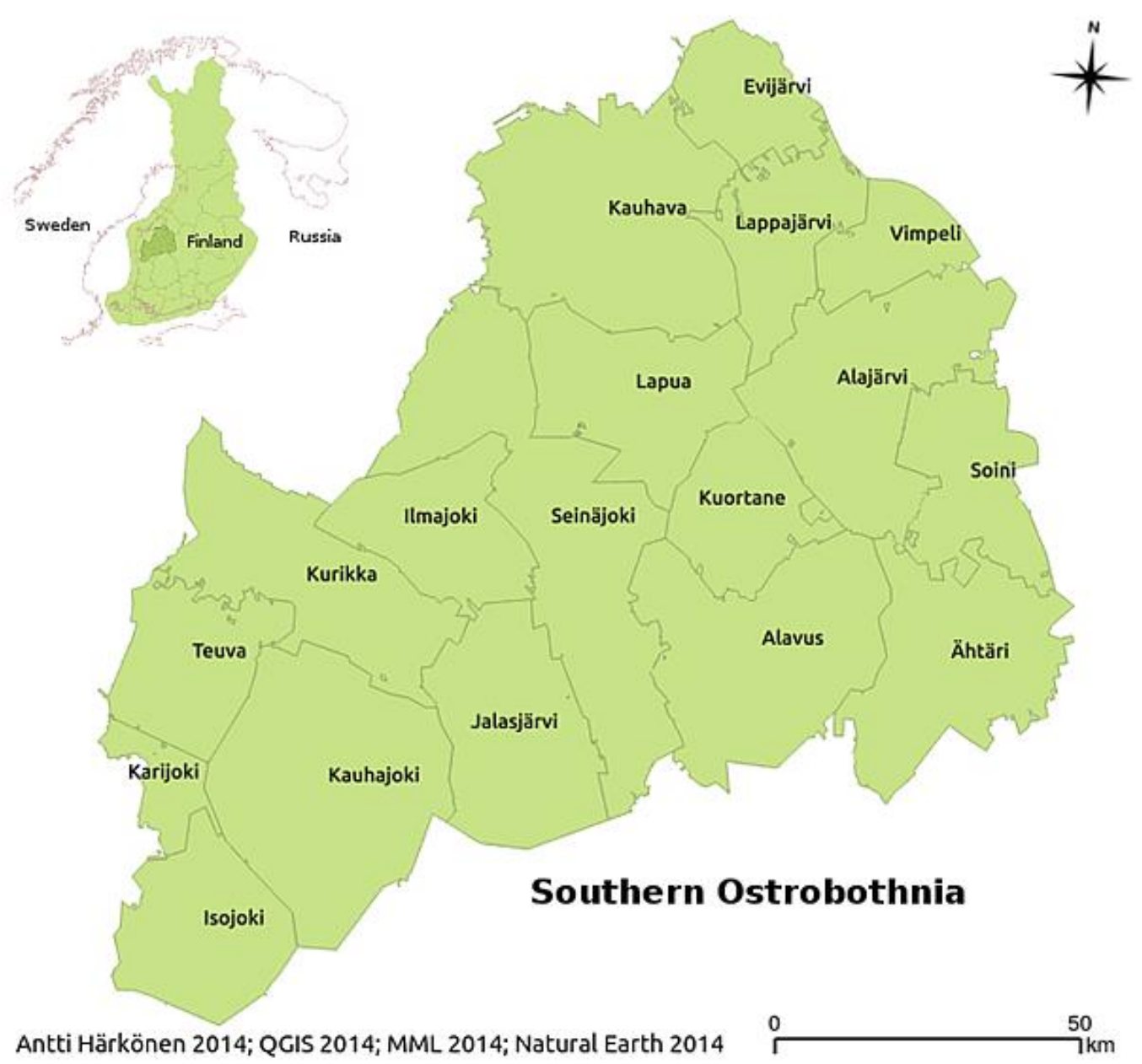

Fig 1. The Southern Ostrobothnia region of western Finland.

The data was obtained from an internet-based survey conducted by the leading regional newspaper Ilkka4 before municipal elections were held in 2008 and 2012. The candidate matcher survey, which national and regional newspapers and TV-channels typically compile before municipal and parliamentary elections every fourth year, comprised of 11-15 structured questions on topics which are seen as contested political issues at a national and/or local level. For instance, the 2008 and 2012 questions concerned immigration and refugee policies, the challenges of local democracy, and questions of general interest regarding services. One of the questions in 2008 was related directly to land use planning and spatial structure. At my request, the newspaper included the same question about the aims of land use planning in 2012, so making it possible to conduct a cross-sectional comparison:

What is the main aim of land use planning: what kind of spatial structure should municipalities promote?

\footnotetext{
4 The circulation of Ilkka is approximately 50000 (in 2012), and it reaches between $15 \%$ and $68 \%$ of households in the municipalities in Southern Ostrobothnia (see http://www.ilkka.fi).
} 
a. Municipalities should promote a dense and concentrated structure. Construction should be allowed only for areas close to existing services and infrastructure.

b. All areas should be developed.

Why? (For a candidate's free form comments), in 2008

The question provided the electoral candidates running for local councils with two options. The first is in line with the Government's revised land use planning guidelines, whereas the second option includes the idea of equality between regions, and is in the vein of earlier planning doctrine and rural cultural traditions.

In 2008, $42 \%$ of the total number of 2112 electoral candidates in 18 municipalities answered the structured question about the main aim of planning. Four years later, a similar share of $43 \%$ of 1994 prospective local politicians answered the same question. These relatively high rates of responses indicate that candidates use the internet-survey (which provides individual citizens with the possibility to compare their opinions to the opinions of prospective candidates) as an integral part of their electoral campaigns. In both years, those who were elected were seen to be more active in expressing their views, than candidates on the average (51\% in 2008 and $53 \%$ in 2012). The members of the seven national parties (Table 1) were more active in responding to the survey than members of minor parties or independent candidates, and the representatives of the regional centre (Seinäjoki) responded more actively than candidates in rural municipalities.

\subsection{Analysis of the qualitative data}

In addition to the structured answers to the question on the main aim of land use planning, this paper examines the free form comments offered by electoral candidates in 2008 . Of the total 554 comments, a dense and concentrated spatial structure was supported in 131 comments, but 423 argued against this option. This analysis of responses utilises deductive content analysis, based on the idea of "an expected pattern" that is tested against observations. In concept, it explores a known theory or phenomenon and tests if it is valid in given circumstances (Patton, 2002: 454; Babbie, 2010: 52).

In this approach, a classification framework was created on the basis of propositions and arguments presented in the Government's new land use planning guidelines (interregional equality vs. ecological sustainability and competitiveness). It transpired that new categories were needed on the basis of the empirical material, as not all of the arguments used by local politicians fitted into this a priori classification. After a step by step process, the final classification framework comprises of eight categories. As some of the comments could not be classified (for instance, if they were too short or their content remained unclear), the classification is not exhaustive. However, overall the typology includes the most typical arguments presented by electoral candidates of the Southern Ostrobothnia region ${ }^{5}$.

\section{What kind of spatial structure should municipalities promote?}

\subsection{Persistence of opinions}

What kind of spatial structure should municipalities promote, and how do local politicians define the main aim of land use planning? Should settlement structure be developed towards fewer and denser residential areas, or should building be allowed in all areas? Table 3 summarises the distribution of politicians' views in different types of municipalities in the Southern Ostrobothnia region. A clear-cut majority of about 80 percent of the prospective local politicians were of the opinion that "all areas should be developed", which is in direct contrast to the Government's new policies. What is particularly interesting here is that this opinion has not changed during the four year term, even though the benefits of a dense and concentrated settlement structure, and the problems of sparsity have become a powerful discourse expressed in the strategies and documents of the Government and several ministries since 2009 when the new national land use planning guidelines came into effect (Sireni, 2011). Local politicians representing small towns and

\footnotetext{
5 The classification of the free form comments of the 554 candidates was carried out in co-operation with human geography students at the University of Joensuu (currently University of Eastern Finland), in 2009.
} 
rural municipalities clearly challenge this discourse and argue against it. Politicians representing the regional centre - the "locomotive which is pulling the growth" of the region - make an important exception to this foremost pattern, as the majority of the politicians elected in both 2008 and 2012 support the Government's new planning policy. As could be expected, the central Government's efforts to strengthen the competitiveness of urban regions and facilitate "an urban renaissance" more likely appears as a positive initiative from the perspective of the urban centres, which compete with rural regions for enterprises and residents.

Tab 3. The distribution of responses of electoral candidates and elected local politicians in Southern Ostrobothnia to the newspaper llkka's internet-based survey question: "What is the main aim of land use planning: what kind of spatial structure should municipalities promote? a. Municipalities should promote a dense and concentrated structure. Construction should be allowed only for areas close to existing services and infrastructure. b. All areas should be developed.

\begin{tabular}{|c|c|c|c|c|c|}
\hline Type of region & Year & $\begin{array}{l}\text { Total number } \\
\text { of candidates } \\
\text { and elected } \\
\text { politicians }\end{array}$ & $\begin{array}{l}\text { Number of } \\
\text { structured } \\
\text { responses }\end{array}$ & $\begin{array}{l}\text { Option a: "A } \\
\text { dense and } \\
\text { concentrated } \\
\text { structure" }\end{array}$ & $\begin{array}{l}\text { Option b: "All } \\
\text { areas should } \\
\text { be developed" }\end{array}$ \\
\hline & 2008 & & & & \\
\hline \multicolumn{6}{|l|}{ Regional Centre } \\
\hline - $\quad$ Candidates & & 300 & 213 & $73(34 \%)$ & $140(66 \%)$ \\
\hline - $\quad$ Elected politicians & & 51 & 34 & $19(54 \%)$ & $15(44 \%)$ \\
\hline \multicolumn{6}{|l|}{ Small towns } \\
\hline - $\quad$ Candidates & & 1024 & 422 & $64(15 \%)$ & $358(85 \%)$ \\
\hline - Elected politicians & & 261 & 143 & $28(20 \%)$ & $115(85 \%)$ \\
\hline \multicolumn{6}{|l|}{ Rural municipalities } \\
\hline - Candidates & & 788 & 257 & $43(17 \%)$ & $214(83 \%)$ \\
\hline - Elected politicians & & 267 & 118 & $16(14 \%)$ & $102(86 \%)$ \\
\hline \multicolumn{6}{|l|}{ Total } \\
\hline - Candidates & & 2221 & 892 & $180(20 \%)$ & $712(80 \%)$ \\
\hline \multirow[t]{2}{*}{ - Elected politicians } & & 579 & 295 & $63(21 \%)$ & $232(79 \%)$ \\
\hline & 2012 & & & & \\
\hline \multicolumn{6}{|l|}{ Regional Centre } \\
\hline - Candidates & & 294 & 175 & $65(37 \%)$ & $110(63 \%)$ \\
\hline - Elected politicians & & 51 & 39 & $20(51 \%)$ & $19(49 \%)$ \\
\hline \multicolumn{6}{|l|}{ Small towns } \\
\hline - $\quad$ Candidates & & 970 & 439 & $81(18 \%)$ & $358(82 \%)$ \\
\hline - $\quad$ Elected politicians & & 253 & 147 & $31(21 \%)$ & $116(79 \%)$ \\
\hline \multicolumn{6}{|l|}{ Rural municipalities } \\
\hline - $\quad$ Candidates & & 730 & 247 & $28(11 \%)$ & $219(89 \%)$ \\
\hline - Elected politicians & & 240 & 100 & $9(9 \%)$ & $91(91 \%)$ \\
\hline \multicolumn{6}{|l|}{ Total } \\
\hline - Candidates & & 1994 & 861 & $174(20 \%)$ & $687(80 \%)$ \\
\hline Elected politicians & & 544 & 286 & $60(21 \%)$ & $226(79 \%)$ \\
\hline
\end{tabular}

How can the persistent resistance of rural politicians be interpreted? The fact that members of local governments support the equal development of all areas even more intensively than the candidates, suggests that their opinion is widely shared by citizens of these rural regions (Table 3). This follows from the fact that the internet-based survey, which can be understood as an integral part of electoral campaign, encourages politicians to avoid arguments which they assume to be unpopular among their potential voters.

Therefore, on the basis of the survey material it can be concluded that the Government's new rhetoric, in which a sparsely populated rural space is constructed as less sustainable and subordinate to internationally competitive and eco-efficient growth centres, has not gained ground amongst the rural population. Rather, it seems that local politicians and voters continue to support the old planning principles and values of the Nordic welfare state, which emphasised social justice and equality between regions and citizens (Othengrafen, 2010). As the tradition of local autonomy 
is strong in Finland, and the history of urbanisation is relatively brief, it will not be a straightforward process to convince ordinary citizens that rural areas have to be "protected" for economic and environmental reasons. In this respect Finland differs from highly urbanised European countries, where the countryside has become culturally and economically urban (Curry and Owen, 2009; Sturzaker and Shucksmith, 2011).

\subsection{Arguments for and against a dense and concentrated spatial structure}

Which arguments are used for and against a dense and concentrated spatial structure by the local politicians? The qualitative comments arguing for a compact and concentrated settlement structure (131 of 554) were classified into four categories (Table 4). The first comprises comments highlighting a concern for the environment. The second and third categories include arguments emphasising competitiveness on two different grounds: either stressing the savings that a dense structure would bring, or arguing for a dense urban milieu as an attractive environment for enterprises, tourists and migrants. The fourth category includes the views of candidates who were of the opinion that although a dense structure is an ideal, planning is a case-specific process and thus a matter of discretion. Therefore the aims of planning cannot be the same in every region.

Tab 4. The classification of 554 qualitative comments of electoral candidates in 2008.

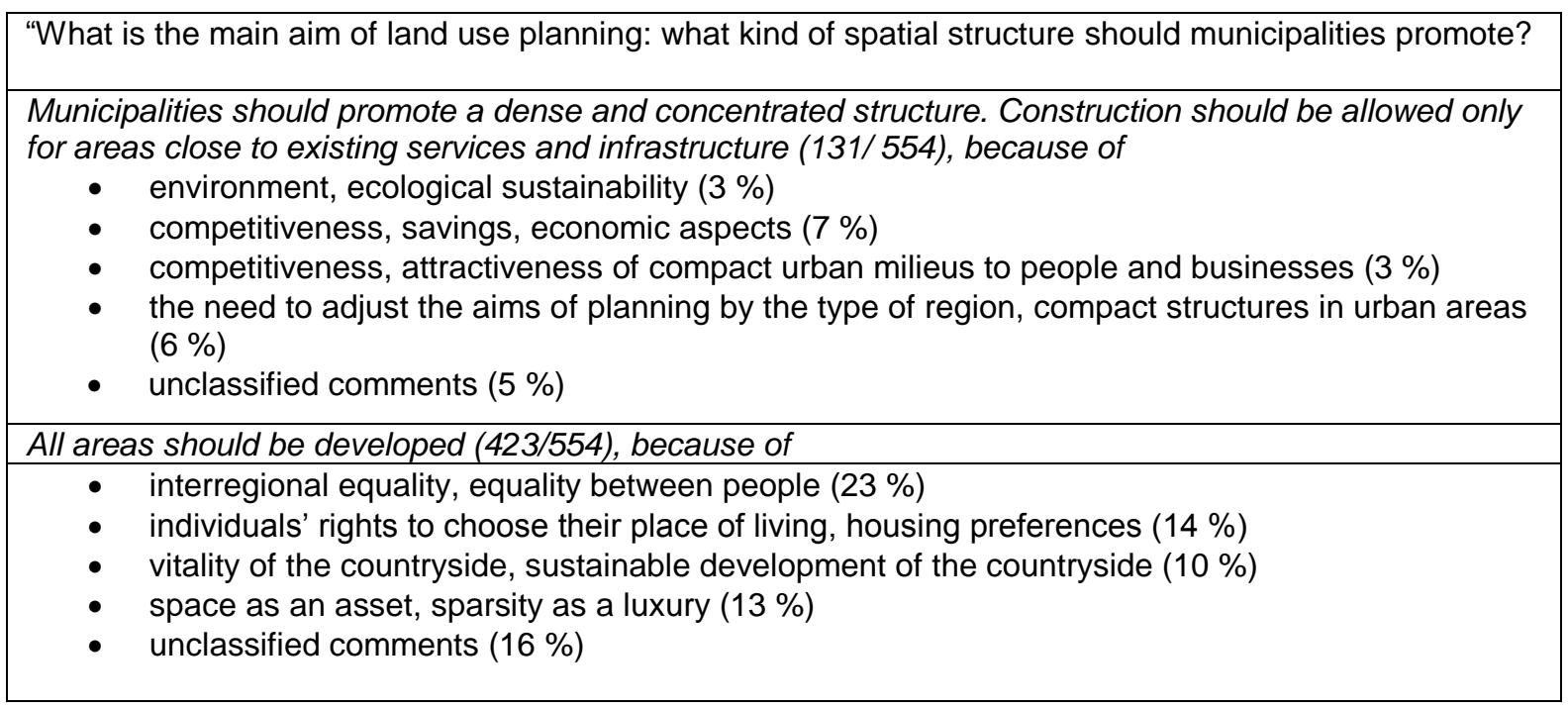

Similarly, the 423 comments which claimed that all parts of the municipalities should be developed and this should also the guiding principle in land-use planning issues were divided into four categories (Table 4). The first category refers explicitly to arguments based on (spatial) equity, and contests the need to develop a more concentrated settlement structure. The second group of candidates emphasised individuals' rights to build wherever they want. In the third group, some politicians stressed that maintaining inhabited and vital rural areas is the foremost priority. The final group did not support a dense structure for the reason that they considered space and sparsity to be a key resource for a municipality in attracting new inhabitants, tourists and businesses. In the following sections of this paper, the four categories supporting a denser structure, and the four categories supporting the development of all areas are described and illustrated with examples.

\subsubsection{In support of the new guidelines}

\section{Environment is not the primary concern}

In spite of the Government's attempts to convince local authorities and policy-makers that building in low-density areas is incompatible with sustainable development, ecological sustainability is not a common argument or motive for the support of a more compact and concentrated settlement structure in the studied region. In fact, only three percent of the 554 free form comments fall into this category (Table 4). Among these respondents, this is typically an urban argument, and most of the prospective politicians who invoke a need to protect the environment represent the regional 
centre. In rural municipalities, the environment is not an important motive for the restriction of housing development in low density areas. What is noteworthy here is that local politicians do not argue against the Government's proposition of a dispersed pattern of development as being less sustainable. It seems that rural politicians who are aware of the fact that inadequate public transport in rural areas will require residents to use cars in the future regardless of the shape of settlement, totally ignore the environmental reasoning behind the new planning policy. In sparsely populated rural regions with a few thousand inhabitants, it is unrealistic to expect that municipalities could be self-sufficient in service provision or that they could develop a wellfunctioning public transport system in the future (see Table 2). Thus, local politicians are very careful in how they formulate their answers, for instance, those who favour a dense structure do not refer to a need to restrict individuals' rights to build in sparsely populated areas, or present any changes to prevailing practices:

"Smart planning and building benefits everybody. Simply, climate change, high energy prices, a need to develop public transport and services are all factors which support a more dense structure". (Social Democratic candidate: Regional centre)

"A more concentrated structure is good for nature; however, municipalities should not prevent people from building in small villages". (Centre Party candidate: Small town)

Clearly, the Government's attempt to take advantage of a growing environmental awareness has not been successful in the Finnish countryside. Due to the autonomous position of rural municipalities, a deep-rooted practice of promoting extensive building rights in the countryside, as well as the condition of sparsity, it is difficult to utilise "discursive power" to portray house building in low density areas as being inherently unsustainable in the eyes of local policy-makers and wider society.

\section{Competitiveness and attractiveness of the countryside is not based on a dense structure}

The new land use planning guidelines suggest that a dense settlement structure would improve the viability of communities through savings achieved mainly in service and infrastructure provision, and through the image of compact centres as eco-efficient milieus for people and businesses. Again it seems that the local politicians do not share these views, and only in seven percent of the free form answers are economic gains or savings seen as the key argument. According to these views, a dispersed settlement structure is assumed to lead to major challenges in maintaining services and infrastructure in rural areas, whereas a centralised structure would bring savings to municipalities:

"A small municipality has no choice other than to promote a dense and more concentrated structure. Otherwise, it is not possible to guarantee basic services for citizens in the area where they live". (Perussuomalaiset candidate: Rural municipality)

"It is very expensive for a small municipality to build infrastructure in every corner. We need the money for the care of elderly people, for instance". (National Coalition Party candidate: Rural municipality)

Not surprisingly, the majority of local politicians representing the countryside have not adopted a rhetoric which emphasises the role of strong (urban) centers as motors of (rural) development. The idea of rural areas as "rail cars" does not fit into the traditional views of equality between regions or the cultural importance of all types of regions (Ministry of the Environment 2006: 11). Only in three percent of the free form comments, is the attractiveness of compact urban milieus for enterprises, tourists and migrants (in particular), used as an argument in support of a dense and concentrated settlement structure. Politicians who typically represent either the regional centre or small towns argue that spatial concentration is a "natural" tendency in present day Finland. In their opinion, people are no longer that interested in living in sparsely populated areas, and the demand for urban environments as living places is gaining ground. The free form answers in this category typically derive from the assertion that the most effective way to develop a municipality is to develop a strong and attractive centre so that this "engine" generates welfare for other parts of the municipality: 
"In the case that we want to develop an attractive town for citizens and tourists, we must get rid of oat fields in the town centre. Let's build a new urban image of Seinäjoki. A densely built town also brings more savings". (Social Democratic candidate: Regional centre)

"It would be ideal to keep all areas inhabited, but under these circumstances this is hardly possible. It is obvious that a strong centre attracts new inhabitants. Thus, only when we have the chance to attract new tax-payers, will we have some chances to also keep small villages alive". (National Coalition party candidate: Small town)

\section{Guidelines need to be differentiated}

The fourth category of free form answers in principle favour a dense structure, and consists of comments which represent positions of compromise between the two contrasting views on the aims of land-use planning (six percent). On one hand, it is claimed that municipalities should promote dense and concentrated patterns of land-use, and that construction should be allowed only in areas close to existing locations of services and infrastructures. However, this is qualified by the argument that all areas should be developed equally. Typically, these local politicians are of the opinion that planning is not a straightforward process, that is, they tend to emphasise that there is usually no one single answer to a question, but that an answer depends on the particular conditions of each case. Following this line of thinking, whilst a compact settlement structure must be the main goal of planning in some cases, there are circumstances in which it is not an important or preferable choice. Variants of this view are shown in comments where politicians challenge the "one size fits all" planning norms, and stress the need to differentiate land use planning guidelines according to the type of region. Rural and urban planning are seen as two different fields, with different aims and means. Many of them seem to favour a case-specific, place-based approach to spatial planning and land use:

"The town centre of Lapua should be compact and concentrated, but at the same time, we must take care of the viability of other areas". (Centre Party candidate: Small town)

"The aims of planning depend on the case". (Centre Party candidate: Rural municipality)

\subsubsection{In support of the welfare state's planning doctrine}

\section{Equality between regions as the key value}

In spite of the changes in the state's policies, the central and widely accepted underlying value affecting planning in the Finnish countryside seems to be one of social justice and equality between regions and between citizens. Almost one quarter $(23 \%)$ of electoral candidates emphasise that citizens, regardless of where they live, should be in an equal position in terms of services and infrastructure (Table 4). They direct their message particularly at those people who live in remote parts of municipalities, paying attention to their rights as citizens and their role as tax-payers. In general, the provision of services dominates this discussion, and service location and access are seen as the key planning issues, whereas housing development largely remains on the sidelines:

"People living in small villages should have the same rights and benefits as others have. Equal possibilities must be guaranteed". (Social Democratic candidate: Rural municipality)

"The continuous centralisation of services causes inequality between citizens". (Centre Party candidate: Small town)

"Services must be available in remote parts of the municipality as well as in the centre. Welfare must be distributed equally". (Centre Party candidate: Rural municipality)

The opinions of rural politicians on what kind of spatial structure municipalities should promote clearly indicate that "social justice" and "equality between regions" is an important underlying value in planning at the local level (Othengrafen, 2010). Local politicians still respect the cultural guidelines of planning formed by the welfare state, although at a national level, these old values have been challenged by pro-business argumentation which emphasises a need to create effective and centralised state space. 


\section{Individuals' rights must be respected}

In a relatively large group of the free form comments (14\%), the political agenda is formulated in terms of an individuals' rights and freedom of choice, claiming that land-use planning must not hinder individuals from building wherever they want to live. According to this line of argumentation, planning should serve citizens' needs, and not restrict economic activity and the migration of new tax-payers. In comments where the concept of rights is discussed, the constitutional right of people to choose their place of living is mentioned:

"Basically, land-use planning should not be an obstacle to people when they choose their place of living". (Christian Democratic candidate: Small town)

"Everybody should have the right to choose his or her place of living, and planning should not prevent it". (Centre Party candidate: Rural municipality)

"In Finland, people have the right to choose their place of living and planning should be used as a tool to help this constitutional right materialise". (Perussuomalaiset candidate: Rural municipality)

These comments suggest that the wish of many Finns to live "close to nature", as well as the importance of a "space of your own" are shared values that are taken for granted by local politicians. Their responses can also be interpreted as reflections of the deep-rooted practice of the extensive "basic building right" in the countryside. As could be expected, old practices and cultural traditions change slowly, and judging from their comments, local politicians in the countryside would seem to hold on to these traditions.

\section{Inhabited rural areas must be maintained}

For $10 \%$ of the local politicians, maintaining rural and sparsely populated inhabited areas is the most important value underlying planning. In this line of thinking, rurality is identified as a central and vital part of the Finnish culture, and as a resource for the Finnish nation. For this reason, it is essential to ensure the possibility for citizens to live in small villages. If building were not to be allowed in all areas, this kind of 'no-development' ethic could lead to a negative spiral in the countryside and endanger its sustainable development:

"Living villages with local innovative people are the corner-stone and a resource of the Finnish lifestyle". (Centre Party candidate: Small town)

In some of the responses which fall into this category, the role of rural areas as "rail cars" is contested and denied. Rural politicians refuse to accept the visions of the new state space in which rural areas have no role in the economy, and they would rather support the former welfare state's regional policy and planning practices which focused on developing the whole of the state area, including remote rural areas.

\section{Sparsity as an asset}

In 13 percent of the free form answers, rural space and sparsity are considered as important resources for municipalities, which can attract new inhabitants by offering spacious sites for building in a beautiful environment. This argument is based on the assumption that potential migrants to rural municipalities are not interested in dense and compact living environments, but rather that they would want to be surrounded by space and nature. The respondents describe typical migrants as families with children, possibly also with dogs or horses, and who need a lot of space around them.

"One important attraction of IImajoki is its sparsely populated regions. I think people should be offered alternatives like that". (National Coalition Party candidate: Rural municipality)

"Living villages are important for the countryside. They are also an asset for us, if we want to be able to compete with big cities for new inhabitants". (National Coalition Party candidate: Small town)

"A Finn needs space around him/her. Dense living causes problems for us". (Christian Democrat candidate: Rural municipality) 
"People move to a rural municipality in order to get more space around them. A dense structure and small sites is not a working system. It was tried in the 1970s and now we have realised that the sites are too small for current purposes". (Centre Party candidate: Rural municipality)

These comments suggest that local politicians are familiar with the wish of many Finns to live "close to nature" and far away from neighbours. Some local politicians see low-density housing as a strategy for rural municipalities to maintain their population level and attract new migrants.

\section{Conclusion}

In Finland, local government units have traditionally had considerable decision-making powers to interpret policy guidelines in regard to land use planning and building rights. Democratically elected local politicians are in a key position when the aims of land use planning are both negotiated and implemented. This paper reports on an investigation concerning local politicians' responses to the new planning norms which have been set by the Finnish government. According to these new national guidelines which originate from (international) urban planning traditions, the desirable ideal in all types of areas - including sparsely populated rural areas - is one of highdensity housing in compact residential areas, close to work places and services. As in many other countries in Europe, this planning ideal is justified on the grounds of environmental, economic and social sustainability.

Drawing on empirical analysis of local politicians' views, this paper shows that the representatives of the predominantly rural Southern Ostrobothnia region of western Finland have not digested the new guidelines and their justifications. Indeed, a clear majority of prospective local decisionmakers, as well as those politicians elected at the 2008 and 2012 local municipal elections have either ignored or challenged them. Most local politicians are of the opinion that all areas within municipalities should be developed, and that house building should not be restricted only to high density areas. In this vein, it can be concluded that the Government's new rhetoric in which sparse rural space is constructed as unsustainable and subordinate to internationally competitive and eco-efficient growth centres, has not gained ground in the countryside.

There are several reasons why it will be a demanding task for the Government to convince local politicians that the new land use planning guidelines will promote environmental, economic and social sustainability in rural areas. Firstly, as the qualitative material of this study reveals, local politicians (and their voters) rely on the old planning principles and values of the Nordic welfare state which revolve around social justice and equality between regions and between citizens, and which have undeniably promoted economic and social sustainability in even the most remote parts of the country. Secondly, as the qualitative comments show, well-established cultural conventions and practices continue to flourish in the countryside. For instance, local politicians highlight the importance of spaciousness to Finns, and emphasise the deep-rooted idea concerning individuals' rights to choose their place of living. Thirdly, the spatial characteristics of Finland are shaped by its sparsity, which in many cases conditions rural regions' possibilities to develop, e.g., an environmentally sustainable public transport system. Therefore, the Government's practical aim to create a more coherent urban structure in order to reduce the volume of traffic is not seen to make much sense in remote areas which lack public transport, and have no realistic prospects to develop transport in the future due to their low population densities. In this vein, the environmental arguments which form the key argumentative thrust of the new national targets, are not presented as important guiding principles at a local level.

Finally, the reluctance of local politicians to adopt the new guidelines is also related to the question of power. From the local perspective, the Government's attempts to intensify its guiding influence causes tension for the reason that there is a long-lasting tradition and well-established culture of local autonomy, which is now being increasingly contested. In practice, rural politicians may also see the danger that power would be lost to central cities, which subsequently get more say in decisions on how the community structure should be developed across the whole region. In addition, rural municipalities typically resist the centralisation policy of a "competition state", and aim at creating economically effective and internationally attractive state space on the grounds that the competition state proceeds at the expense of social justice and equality between regions. Therefore, as long as the implementation of land use planning remains in hands of local 
politicians, it will be difficult to use discursive power to overcome their actual decision making power.

References

[1] Alexander, D. (2006). Rural policy, rural communities and the planning system, Town \& Country Planning, 75(12), 351-355.

[2] Babbie, E. (2010). The practice of social research, $12^{\text {th }}$ edition, Wadsworth: Cengage Learning.

[3] Böhme, K. (2002). Nordic Echoes of European Spatial Planning: Discursive Integration in Practice, Nordregio Report 2002:8, Stockholm: Nordregio.

[4] Curry, N. \& Owen, S. (2009). Rural planning in England. Town Planning Review 80(6), 575595. DOI:10.3828/tpr.2009.13.

[5] Damsgaard, O., Dubois, A., Gløersen, E., Hedin, S., Rauhut, D., Roto, J., Schmitt, P. \& Steinecke, J. M. (2008). Nordic inputs to the EU Green Paper on Territorial Cohesion, Nordregio Working Paper 2008:4, Stockholm: Nordregio.

[6] EEA (European Environmental Agency) (2006). Urban sprawl in Europe. The ignored challenge, EEA Report 10/2006, Copenhagen: European Commission, European Environmental Agency.

[http://www.eea.europa.eu/publications/eea_report_2006_10/eea_report_10_2006.pdf].

[7] Gkartzios, M. \& Scott, M. (2010). Residential mobilities and house building in rural Ireland: evidence from three case studies. Sociologia Ruralis 50(1), 64-84. DOI: 10.1111/j.14679523.2009.00502.x

[8] Gløersen, E., Dubois, A., Copus, A. \& Schürmann, C. (2005). Continuity of Transformation? Perspectives on Rural Development in the Nordic Countries. Northern Peripheral, Sparsely Populated Regions in the European Union, Nordregio Report 2005: 4, Stockholm: Nordregio.

[9] Harvold, K. \& Nordahl, B. (2012). Planning in Rurbania: rural policy and the planning system in Norway, Town Planning Review 83(2), 213-232. DOI: 10.3828/tpr.2012.12.

[10] Helminen, V. \& Ristimäki, M. (2007). Kaupunkiseutujen haja-asutusalueen väestömuutokset Suomessa 1980-2005. Suomen ympäristö 9/2007. Helsinki: Ympäristöministeriö.

[11] Hiltunen, M. J. \& Rehunen, A. (2014). Second home mobility in Finland: Patterns, practices and relations of leisure oriented mobile lifestyle. Fennia - International Journal of Geography, 192(1), 1-22. DOI: 10.11143/8384.

[12] Juntto, A. (2007). Suomalaisten asumistoiveet ja mahdollisuudet, Helsinki: Tilastokeskus, Ympäristöministeriö.

[13] Katajamäki, H. (1991). Suomen maaseudun suuri kertomus. Terra 103(3), 173-183.

[14] Kettunen, P. (2001). The Nordic welfare state in Finland. Scandinavian Journal of History 26(3), 225-247.

[15] Kortteinen, M. Tuominen, M. \& Vaattovaara, M. (2005). Asumistoiveet, sosiaalinen epäjärjestys ja kaupunkisuunnittelu pääkaupunkiseudulla. Yhteiskuntapolitiikka 70(2), 121131.

[16] Lapintie, K. (2010). Intohimon hämärä kohde. Mitä asukas haluaa? Yhdyskuntasuunnittelu 48(2), 41-57.

[17] Lapping, M. B. (2006). Rural policy and planning (pp. 104-122). In Cloke, P., Marsden, T. \& Mooney, P. H., eds., Handbook of Rural Studies, London: SAGE.

[18] Ministry of the Environment (2006). Competitiveness, well-being and eco-efficiency. Perspectives for spatial structure and land-use in Finland, The Finnish Environment 31en/2006, Helsinki: Ympäristöministeriö. 
[19] Ministry of the Environment (2009). The future of land-use is being decided now. The Revised National Land Use Guidelines of Finland, Helsinki: Ympäristöministeriö.

[20] Ministry of the Environment (2012). Kyläyleiskaavoitus. Opas kaavoittajille, kunnille ja kylille, Suomen ympäristö 3/2012, Helsinki: Ympäristöministeriö.

[21] Ministry of the Finance (2012). Elinvoimainen kunta- ja palvelurakenne. Kunnallishallinnon rakennetyöryhmän selvitys, Osa I, Valtiovarainministeriön julkaisuja, Kunnat 5a/2012, Helsinki: Valtiovarainministeriö.

[http://www.vm.fi/vm/fi/04_julkaisut_ja_asiakirjat/01_julkaisut/03_kunnat/20120206Elinvo/0 01_Kuntauudistusraportti_suomi_osa1_finalNETTI.pdf].

[22] Mäntysalo, R., Saglie, I. \& Cars, G. (2011). Between Input Legitimacy and Output Efficiency: Defensive Routines and Agonistic Reflectivity in Nordic Land-Use Planning. European Planning Studies 19(12), 2109-2126. DOI: 10.1080/09654313.2011.632906.

[23] Moisio, S. (2008). Towards attractive and cost-efficient state space: Political geography of the production of state transformation in Finland. World Political Science Review 4(3), 1-34.

[24] Moisio, S. \& Leppänen, L. (2007). Towards a Nordic competition state? Politicoeconomic transformation of statehood in Finland 1965-2005. Fennia 185(2), 63-87.

[25] OECD (Organisation for economic co-operation and development) (2005). Finland: OECD Territorial Reviews, Paris: OECD.

[26] Othengrafen, F. (2010). Spatial planning as expression of culturised planning practices. Town Planning Review 81(1), 83-110. DOI: 10.3828/tpr.2009.25.

[27] Patton, M. Q. (2002). Qualitative Research \& Evaluation Methods, $3^{\text {rd }}$ Edition, Thousand Oaks (CA): SAGE.

[28] Remahl, T. (2008). Aluepolitiikan yhteiskunnalliset merkitykset ja muutos. Hyvinvointivaltiosta kilpailuvaltioon, Nordia Geographical Publications Vol 37: 5, Publications of the Geographical Society of Northern Finland and the Department of Geography, Oulu: University of Oulu.

[29] Rosenqvist, O. (2003). Kilpailukykyisen maaseudun tuottaminen keskittyvän aluekehityksen ja hegemonisen kaupunkidiskurssin oloissa. Terra 115(1), 3-18.

[30] Sireni, M. (2010). Sparsity as Luxury? An analysis of rural politicians' views on building rights in low density areas in Finland (pp. 310-321). In Ache, P. \& Ilmonen, M., ed., Space is luxury. Helsinki: Aalto University.

[31] Sturzaker, J. (2010). The exercise of power to limit the development of new housing in the English countryside. Environment and Planning $A$ 42(4), 1001-1016. DOI: 10.1068/a42297.

[32] Statistics http://www.kunnat.net/fi/tietopankit/tilastot/yleistilastoja_kunnittain/Sivut/default.aspx.

[33] Sturzaker, J. \& Shucksmith, M. (2011). Planning for housing in rural England. Discursive power and spatial exclusion. Town Planning Review 82(2), 169-192. DOI: 10.3828/tpr.2011.11.

[34] The Centre Party (2008). Äänestä kotiasi. Keskustan kunta- ja maakuntaohjelma 2008. www.keskusta.fi.

[35] The Christian Democrats (2008). Kotikunta kuuluu kaikille. Kristillisdemokraattien kuntavaaliohjelma 2008. www.kd.fi.

[36] The Greens (2008). Oikeudenmukaisuus, valinnanvapaus, ilmastovastuu. Vihreän liiton kunnallisvaaliohjelma 2008. www.vihreat.fi.

[37] The Finnish Social Democratic Party (2008). Unelmista todeksi - sanoista teoiksi. Sosialidemokraattinen kuntavaaliohjelma 2008. www.sdp.fi. 
[38] The Left Alliance (2008). Vasemmistoliiton kunnallisvaaliohjelma 2008. www.vasemmistoliitto.fi.

[39] The National Coalition Party (2008). Kaikkien kuntien tekevät inmiset liittykää yhteen. Kokoomuksen kunnallisvaaliohjelma. www.kokoomus.fi.

[40] True Finns (2008). Perussuomalaisten kunnallisvaaliohjelma 2008 - Äänestäjän asialla. www.perussuomalaiset.fi.

[41] Vaattovaara, M., Schulman, H. \& Kortteinen, M. (2011). A Nordic Welfare model at a turning point? Social housing and segregation in Finland (pp. 49-70). In Driant, J.-C. \& Houard, N., ed., Social housing across the Europe. Paris: La documentation Francaise.

[42] Vasanen, A. (2012). Beyond stated and revealed preferences: the relationship between residential preferences and housing choises in the urban region of Turku, Finland. Journal of Housing and Built Environment 27(3), 301-315. DOI: 10.1007/s10901-012-9267-8.

[43] Vepsäläinen, M. \& Pitkänen, K. (2010). Second home countryside. Representations of the rural in Finnish popular discourses. Journal of Rural Studies. 26(2), 194-204. DOI: 10.1016/j.jrurstud.2009.07.002. 